\title{
Teachers in a World of Change: Teachers' Knowledge and Attitudes towards the Implementation of Innovative Technologies in Schools
}

\author{
Orit Avidov-Ungar and Yoram Eshet-Alkakay \\ Dept. of Education and Psychology, Open University, \\ Raanana, Israel
}

oritav@openu.ac.il; yorames@openu.ac.il

\begin{abstract}
The implementation of innovative technologies in school is a complex process that enquires creating a pedagogical, technological, and managerial systemic change in the school-culture - a process that usually fails to meet the high expectations and to create the systemic change.

In light of the many recent studies, which indicate that teachers' perception and attitudes play a pivotal role of in the success or the failure of technology-implementation projects, the present study explores the teachers' perceptions and attitudes towards the implementation of an innovative technology (smart class) in school by analyzing the inter-relationships between the major pedagogical factors that act in a technology-implementation process: (1) the teachers' attitudes towards change, (2) the teachers' technological-pedagogical content knowledge, and (3) the teachers' perception of school as a learning organization. Data was gathered using questionnaires that captured the teachers' level of "Technological Pedagogical Content Knowledge" (TPACK), their perception of school as a learning organization, and their attitude towards change. Findings indicate a positive correlation between TPACK and the teachers' attitudes towards change, and a positive correlation between teachers' attitudes towards change and their perception of school as a learning organization. Participants who scored high in TPACK and in perceiving their school as a learning organization also scored high in their positive attitudes towards change.
\end{abstract}

Key words: TPACK, attitude; teacher's attitudes towards change, school as a learning organization, innovative technology, educational technology, smart class; educational change

\section{Introduction}

Recent studies indicate that the implementation of innovative technologies in schools demand a systemic change in the school-culture (H. Becker, 2001; Eshet, 2007; Coffman, 2009; Cuban, 1988; Kent \& MacNergney, 1999; Wal-

Material published as part of this publication, either on-line or in print, is copyrighted by the Informing Science Institute. Permission to make digital or paper copy of part or all of these works for personal or classroom use is granted without fee provided that the copies are not made or distributed for profit or commercial advantage AND that copies 1) bear this notice in full and 2) give the full citation on the first page. It is permissible to abstract these works so long as credit is given. To copy in all other cases or to republish or to post on a server or to redistribute to lists requires specific permission and payment of a fee. Contact Publisher@InformingScience.org to request redistribution permission. lace, 2004) and involves a wide range of pedagogical, technological, and managerial factors, whose inter-relationships are not fully understood (Cunningham, 2009; Darling-Hammond, 2000; Day \& Smethem, 2009; Fullan \& Smith, 1999; Halverson \& Smith, 2009). Most studies of technology-implementation in school systems report on disappointment from the projects' outcomes (Avidov-Ungar,

\section{Editor: Alex Koohang}

An earlier, shorter version of this paper was presented at the Chais conference 2011, in Raanana, Israel, and included in Y. Eshet-Alkalai, A. Caspi, S. Eden, N. Geri, \& Y. Yair (Eds.), Proceedings of the Chais conference on instructional technologies research 2011: Learning in the technological era. Raanana: The Open University of Israel. http://www.openu.ac.il/research center/chais2011/papers.html 
2010; Day \& Smethem, 2009; De Val \& Fuentes, 2003; Halverson \& Smith, 2009; Mioduser, Nachmias, Forkosh, \& Tubin, 2004) and emphasize the pivotal role of the teachers' pedagogical perspectives and beliefs in its success (De Freitas \& Oliver, 2005; Selwyn, 2010). This claim was illustrated in the meta-analysis of thousands of technology-integration projects (Hattie, 2009), which found that the best predictors of students' achievements are related to teachers' activities and not to the technology itself. This emphasizes the importance of studying the teachers' perspectives and beliefs in the context of a technology-implementation project and the interrelationships between teacher-related variables that affect the project's success (Levin \& Fullan, 2008).

Studies of the factors that affect the success of implementing change in school in general and innovative technologies in particular (Fullan, 2000; Kontoghiorghes, Awbre, \& Feurig, 2005; Sandy, 2010) indicate that the three major success factors are: (1) the teachers' attitudes towards change, (2) the teachers' contextual pedagogic and technological knowledge, and (3) the teachers' perception of school as a learning organization. This study explores the correlation between these three factors, in the context of a systemic change, related to the implementation of innovative "smart classes" in school. Below is a brief description of each of the three factors.

\section{Teachers' Attitudes towards Change}

The teachers' attitudes towards change and their readiness to become active partners is considered a critical success factor (Avidov-Ungar, 2010; Coffman, 2009; Day \& Gu, 2007; Fullan \& Smith, 1999). Similarly, resistance to change is considered one of the main reasons for failure of processes that involve change in organizations in general and in the educational systems in particular (Fullan \& Hargreaves, 1996; Zimmerman, 2006). In the case of innovative technology implementation in schools, teachers' resistance is reported by some studies to be the most important factor in the project's success (Del Val \& Fuentes, 2003), mainly because the technology doesn't fit to their pedagogical practices and beliefs (Halverson \& Smith, 2009; Harris \& Hofer 2009). According to Del Val and Fuentes (2003), resistance to change is divided into cognitive resistance (focused on identifying and presenting weaknesses of the change and enlisting claims and reasons for maintaining the existing situation) and emotional resistance (focused on expressing negative feelings towards the change, such as anger, disdain, hostility or sadness). Emotional resistance is also accompanied by psychological symptoms such as tension, impatience, pessimism, apathy and disinterest. In many cases, resistance to change becomes active resistance, in which participants actively sabotage the process of change (Zimmerman, 2006).

\section{Teachers' Technological Pedagogical Content Knowledge (TPACK)}

Teaching in a technological environment faces teachers with a wide range of pedagogical, cognitive and ergonomic challenges (Eshet, 2004; 2007; Koehler \& Mishra, 2009, 2008; Mishra \& Koehler, 2006). Unfortunately, most teachers are not trained to teach in technological environments (Day \& Smethem, 2009), and many of them report on difficulties in effective integration of technologies in their teaching (De Freitas \& Oliver, 2005).

Following Shulman's (1987) definitions of good teaching, in educational projects the teachers' perception of their knowledge is considered a critical success factor (Polly \& Mims 2009). In technology-implementation projects this knowledge is described as a blend of Technology, Pedagogy, and Content Knowledge (TPACK) (Harris, Mishra \& Koehler, 2009; Mishra \& Koehler, 2006) - knowledge that teachers must master in order to use the technology effectively (Doering, Veletsianos, Scharber, \& Miller, 2009; Polly, \& Mims, 2009). According to Cunningham (2009), the interaction between the three TPACK components (i.e., technology, pedagogy, and content knowledge) creates seven types of knowledge (Table 1) and can be regarded as a measure of 
teachers' ability to integrate innovative technologies effectively into their teaching. These seven types of knowledge are derived from the three major topics (i.e. pedagogy, technology, and content, or PK, TK and CK respectively), three interactions between the three topics (Pedagogical Technological Knowledge, Technological Content Knowledge and Technological Pedagogical Knowledge - or PCK, TCK and TPK respectively), and the seventh type of knowledge - TPACK - results from the interaction between all the six types of knowledge (Table 1).

Table 1: The seven types of knowledge included in TPACK (modified from Mishra \& Koehler (2006))

\begin{tabular}{|l|l|}
\hline Type of knowledge & Description \\
\hline Content knowledge CK & $\begin{array}{l}\text { Knowledge of facts and proofs in a specific domain; knowledge } \\
\text { bases of the subject taught }\end{array}$ \\
\hline $\begin{array}{l}\text { Pedagogical knowledge } \\
\text { PK }\end{array}$ & $\begin{array}{l}\text { Extensive knowledge of the teaching and learning processes and } \\
\text { methods that includes educational goals, values and targets. A } \\
\text { teacher with thorough pedagogic knowledge understands how } \\
\text { students construct their knowledge, acquire skills and develop } \\
\text { learning habits, and thus knows which methods to use so that the } \\
\text { student understands }\end{array}$ \\
\hline $\begin{array}{l}\text { Technological knowl- } \\
\text { edge }\end{array}$ & $\begin{array}{l}\text { This knowledge includes cognitive methods and working with } \\
\text { technology, familiarity with the technological potential, and with } \\
\text { the technical and pedagogical principles of the technology }\end{array}$ \\
\hline $\begin{array}{l}\text { Pedagogical content } \\
\text { knowledge }\end{array}$ & $\begin{array}{l}\text { This knowledge embraces the core of teaching, learning, curricu- } \\
\text { lum, evaluation and reporting and demands flexible lesson plan- } \\
\text { ning and implementation }\end{array}$ \\
\hline $\begin{array}{l}\text { Technological content } \\
\text { knowledge TCK }\end{array}$ & $\begin{array}{l}\text { This knowledge is the understanding of the way in which technol- } \\
\text { ogy and the content influence, and are influenced by, each other. } \\
\text { Teachers should know which technologies are suitable for the } \\
\text { topic studied and how the content is influenced or changes due to } \\
\text { the technology, and vice versa }\end{array}$ \\
\hline $\begin{array}{l}\text { Technological peda- } \\
\text { gogical knowledge } \\
\text { TPK }\end{array}$ & $\begin{array}{l}\text { This knowledge is the teacher's ability to see the pedagogic pos- } \\
\text { sibilities embodied in the technological tools originally developed } \\
\text { for purposes other than educational, and to explore how they can } \\
\text { be used to advance students. This is the understanding of how } \\
\text { the use of technology can change learning and teaching }\end{array}$ \\
\hline $\begin{array}{l}\text { TPACK } \\
\text { ognow knowledge is the basis for effective teaching using technol- } \\
\text { oontextual, the pedagogical and the technological knowledge } \\
\text { when "the sum is greater than the parts" and differs from the } \\
\text { knowledge of each part individually. Thus every teaching situation } \\
\text { using technology presents the teacher with the combination of the } \\
\text { three factors. }\end{array}$ \\
\hline
\end{tabular}

Archambault \& Crippen (2009) used TPACK to measure teachers' perception of their teaching in a technology-based environment. Based on their findings, they argue that TPACK can be used as a reliable measure of teaching quality in such environments. 


\section{School as a Learning Organization}

The constant introduction of innovative educational technologies requires that schools develop an organizational learning culture, a culture which helps maintain transfer of knowledge, creativity, flexibility, and support, which are critical for coping effectively with the never-ending changes in educational technologies (Collinson, 2010; Coppieters, 2005; Fauske \& Raybould, 2005; Giles \& Hargreaves, 2006; Senge, Cambron-McCabe, Lucas, Smith, Dutton \& Kleiner, 2000; Zhao \& Ordonez de Pablos, 2009; Weldy \& Gillis, 2010). This is issue is also discussed in Negroponte's "Being Digital" thesis (1995) in which he emphasized cooperation and cooperative learning as characteristic elements in schools which maintain a learning organizational culture. Research shows that schools which maintain a learning organizational culture are able to cope more successfully with systemic changes dictated by technological innovation (Giles \& Hargreaves, 2006; Kontoghionghes et al., 2005; Tas, 2005; Yu-Lin \& Ellinger, 2008; Zhao \& Ordonez de Pablos, 2009). Some researchers even claim that there is no point in integrating technologies in schools that don't maintain a learning organizational culture (Weldy \& Gillis, 2010; Lieberman, 1995; Tatnall \& Davey, 2003).

In recent years, there is a growing amount of evidence that the perception of teachers of their school as a learning organization affects their readiness to become active partners in technologyintegration projects, and consequently, affects the project's success (Levin \& Fullan, 2008; Ogobonna \& Harris, 2003; Vaillant, 2005; Zimmerman, 2006).

\section{The Research Background}

During the year 2009, the Israeli's Ministry of Education introduced the "smart classrooms" project in 100 schools in southern Israel. The project's goal was to provide a unique innovative technological platform that will lead to a technological educational reform in teaching methods and in student-teacher relationships (C. Becker \& Lee, 2009). Smart classes consist of a variety of technological devices, such as Internet connectivity, computers, projectors, and interactive boards. They enable teachers to prepare, project and share learning materials, and create a new kind of teacher-student dialogue (Way, Lilley, Ruster, Johnco, Mauric, \& Ochs, 2009). This study explores the perceptions, attitudes, and knowledge of teachers who participated in the project.

\section{Methodology}

\section{Goals}

This study explored the inter-relationships between the 3 major factors that involve change in a technology-integration project: teachers' Technological Pedagogical Content Knowledge (TPACK), teachers' perception of school as a learning organization, and teachers' attitudes towards change. It examined the following connections:

- Connection between teachers' technological pedagogical content knowledge (TPACK) and their attitudes towards change.

- Connection between teachers' perception of school as a learning organization and their attitudes towards change.

\section{Research Population}

Participants were one hundred teachers from eight elementary schools in southern Israel. For all of them it was the first year of participating in the "smart class" project. $74.2 \%$ of the participants had more than ten years of teaching experience, 5.4\% had 7-9 years, $14 \%$ had $4-6$ years, and $6.5 \%$ had $1-3$ years of experience. $66.3 \%$ had a B.A., $22.8 \%$ a M.A. and $10.9 \%$ lacked an aca- 
demic degree. $55.7 \%$ of the participants reported that they are in an expert stage of their career, $32.9 \%$ reported of an Intermediate stage ("moderate-to-high level"), 8.9\% reported that they are at a "preliminary level" and $2.5 \%$ reported that they are at a beginners stage of their career. $66.2 \%$ of the participants taught three or more subjects at school, 15.6\% taught two subjects, and 18.2\% taught one subject.

\section{Research Tools}

Data was gathered, using a self-report 1-7 Leichert Scale questionnaire, which consisted of the following three components:

\section{Technological Pedagogical Content Knowledge (TPACK) questionnaire (Archambult \& Crippen, 2009; Cox \& Graham, 2009)}

This 24-item questionnaire is divided into the following seven types of knowledge that teachers should master in order to effectively implement and use innovative technologies in teaching: Pedagogical Knowledge (PK), Technological Knowledge (TK), Content Knowledge (CK), Technological Content Knowledge (TCK), Pedagogical Content Knowledge (PCK), Technological Pedagogical Knowledge (TPK), and Technological Pedagogical Content Knowledge (TPACK). The questionnaire has a high level of reliability: $\alpha=0.97$.

\section{Perception of school as a learning organization questionnaire}

This 44-item questionnaire explored the teachers' perceived level of organizational learning in school (Korland, 2000), examining two aspects: (1) whether the processes that characterize a learning organization actually exist in school; (2) whether these processes are actually important for the effectiveness of the school's functioning. The questionnaire referred to four of the following major organizational learning processes at school:

1. Learning processes

2. Evaluation and drawing conclusions

3. Disseminating information and knowledge

4. Gathering and preserving information and knowledge

The questionnaire has a high level of reliability: $\alpha=0.82$

\section{Attitudes towards change questionnaire}

This 16-item questionnaire examined attitudes and resistance to change among the participants cognitive, emotional, and behavioral. The questionnaire has a high level of reliability: $\alpha=0.94$

\section{Findings}

\section{A. Teachers' Attitudes towards Changes}

Table 2 presents the cognitive, emotional, and behavioral attitudes of teachers towards change that were gathered by the Attitudes towards Change questionnaire. From the table, it is evident that the participants, in general, show a very positive attitude towards change, with the behavioral attitudes being the highest (5.70) and the emotional attitudes being the lowest (4.92). The Cognitive attitudes are ranked in the middle (5.03). 
Table 2: Teachers' attitudes towards change $(\mathrm{N}=100)$

\begin{tabular}{lll}
\hline & Average & SD \\
& & \\
\hline Cognitive attitudes & 5.03 & 0.75 \\
\hline Emotional attitudes & 4.92 & 0.90 \\
\hline Behavioral attitudes & 5.70 & 0.68 \\
\hline
\end{tabular}

\section{B. Teachers' Technological Pedagogical Content Knowledge} (TPACK)

TPACK findings are summarized in Table 3 according to the seven types of knowledge it consists of.

Table 3: Technological pedagogical content knowledge (TPACK) according to its components

\begin{tabular}{lcc}
\hline & Average & SD \\
\hline Pedagogical knowledge PK & 3.92 & 0.74 \\
\hline Technological knowledge TK & 3.00 & 1.17 \\
\hline Content knowledge of the subject CK & 4.00 & 0.78 \\
\hline Technological content knowledge TCK & 3.63 & 0.94 \\
\hline Pedagogical content knowledge PCK & 4.07 & 0.71 \\
\hline Technological pedagogical knowledge TPK & 3.53 & 0.96 \\
\hline $\begin{array}{l}\text { Technological pedagogical content } \\
\text { knowledge TPACK }\end{array}$ & 3.41 & 0.87 \\
\hline
\end{tabular}

Table 3 indicates that the self-reported level of teachers' knowledge for all seven TPACK components is moderate to high. The highest score was obtained for the Pedagogical Content Knowledge (PCK) (4.07), indicating the high self-confidence of teachers in the subject-matter they teach. In contrast, the lowest score (3.0) was found in the Technological Knowledge (TK), representing the low self-confidence of teachers in using technology for teaching. The high standard deviation found for Technological Knowledge (1.17) indicates the co-existence of two teachers' groups: One with a high and one with a low mastery level of technology for teaching.

\section{Teachers' Attitudes towards School as a Learning Organization}

The Table 4 depicts the teachers' perception of school as a learning organization for four the major learning processes of organizational learning (Korland, 2000). Findings illustrate the importance that teachers assign to the organizational learning processes in school. On the other hand, the significant differences between the two columns in Table 4 reveal a large gap between the level of organizational processes that the teachers would expect to have in their schools, and the level that actually exist there. 
Table 4: Teachers' perception of school as a learning organization

\begin{tabular}{lcccc}
\hline $\begin{array}{l}\text { Organizational learn- } \\
\text { ing processes }\end{array}$ & $\begin{array}{l}\text { To what extent do } \\
\text { behaviors of a } \\
\text { learning organiza- } \\
\text { tion exist in } \\
\text { school? }\end{array}$ & $\begin{array}{l}\text { How important are be- } \\
\text { haviors of a learning } \\
\text { organization in } \\
\text { school? }\end{array}$ & SD \\
\cline { 2 - 5 } & $\mathbf{M}$ & SD & M & SD \\
\hline Learning processes & 4.07 & 0.80 & 4.43 & 0.56 \\
\hline $\begin{array}{l}\text { Evaluating \& drawing } \\
\text { conclusions }\end{array}$ & 3.99 & 0.86 & 4.51 & 0.67 \\
\hline $\begin{array}{l}\text { Disseminating infor- } \\
\text { mation \& knowledge }\end{array}$ & 4.09 & 0.73 & 4.43 & 0.59 \\
\hline $\begin{array}{l}\text { Gathering and pre- } \\
\text { serving information \& } \\
\text { knowledge }\end{array}$ & 3.91 & 0.88 & 4.44 & 0.69 \\
\hline
\end{tabular}

A weak, negative and significant correlation $\left(\mathrm{r}_{(87)}=-0.227, \mathrm{p}<0.05\right)$ was found between teaching seniority and the reported level of evaluation and drawing conclusions processes at school. A weak, negative and significant correlation $\left(\mathrm{r}_{(87)}=-0.270, \mathrm{p}<0.05\right)$ was found between teaching seniority and the scores for gathering and preserving information and knowledge processes at school.

\section{Correlation between TPACK and Attitudes towards Change}

Examination of the correlation between the teachers' attitudes towards change and the indices of the TPACK questionnaire was conducted, using Pearson tests, as shown in Table 5.

Table 5: Correlation between TPACK and teachers' attitudes towards change

\begin{tabular}{|c|c|c|c|c|c|c|c|}
\hline $\begin{array}{c}\text { Technological } \\
\text { pedagogical } \\
\text { content } \\
\text { knowledge } \\
\text { (TPACK) }\end{array}$ & $\begin{array}{c}\text { Technological } \\
\text { Pedagogical } \\
\text { knowledge } \\
\text { (TPK) }\end{array}$ & $\begin{array}{c}\text { Pedagogical } \\
\text { Content } \\
\text { knowledge } \\
\text { (PCK) }\end{array}$ & $\begin{array}{c}\text { Technological } \\
\text { content } \\
\text { knowledge } \\
\text { (TCK) }\end{array}$ & $\begin{array}{c}\text { Content } \\
\text { knowledge } \\
\text { (CK) }\end{array}$ & $\begin{array}{c}\text { Technological } \\
\text { knowledge } \\
\text { (TK) }\end{array}$ & $\begin{array}{c}\text { Pedagogical } \\
\text { knowledge } \\
\text { (PK) }\end{array}$ & \\
\hline $0.229^{*}$ & $0.272^{* \star}$ & 0.146 & 0.188 & $0.345^{\star *}$ & 0.176 & $0.283^{* \star}$ & $\begin{array}{l}\text { Attitudes } \\
\text { towards } \\
\text { change } \\
\text { general }\end{array}$ \\
\hline $0.247^{*}$ & $0.239^{*}$ & 0.170 & 0.191 & $0.271^{* *}$ & 0.178 & $0.288^{* *}$ & $\begin{array}{l}\text { Cognitive } \\
\text { attitudes }\end{array}$ \\
\hline $0.237^{*}$ & $0.263^{*}$ & 0.171 & $0.222^{* \star}$ & $0.372^{* *}$ & 0.175 & $0.297^{* *}$ & $\begin{array}{l}\text { Emotional } \\
\text { attitudes }\end{array}$ \\
\hline-0.044 & 0.061 & -0.34 & -0.044 & 0.102 & -0.034 & 0.036 & $\begin{array}{l}\text { Behav- } \\
\text { ioral atti- } \\
\text { tudes }\end{array}$ \\
\hline
\end{tabular}

* Significant at the level of $p<0.05$

** Significant at the level of $p<0.01$ 
It is evident from Table 5 that Pedagogical Knowledge (PK) has a significant, weak, positive connection with the attitude towards change $\left(\mathrm{r}_{(96)}=0.283, \mathrm{p}<0.05\right)$, both with the cognitive attitudes $\left(\mathrm{r}_{(96)}=0.288, \mathrm{p}<0.05\right)$ and the emotional attitudes $\left(\mathrm{r}_{(96)}=0.297, \mathrm{p}<0.05\right)$. Content Knowledge $(\mathrm{CK})$ was found to have a significant positive correlation with the attitudes towards change $\left(r_{(94)}=0.345, p<0.01\right)$, both to the cognitive attitudes $\left(r_{(94)}=0.271, p<0.01\right)$ and to the emotional attitudes $\left(\mathrm{r}_{(94)}=0.372, \mathrm{p}<0.01\right)$. A significant, positive weak correlation $\left(\mathrm{r}_{(94)}=0.222, \mathrm{p}<0.05\right)$ was found between Technological Content Knowledge (TCK) and emotional attitudes towards change. A significant weak correlation was found between Technological Pedagogical Knowledge (TPK) and the average attitudes towards change $\left(r_{(94)}=0.272, p<0.01\right)$ - both with the cognitive attitudes $\left(\mathrm{r}_{(94)}=0.239, \mathrm{p}<0.05\right)$ and to the emotional attitudes $\left(\mathrm{r}_{(94)}=0.263, \mathrm{p}<0.05\right)$. A significant weak correlation was found between Technological Pedagogical Content, Knowledge (TPACK) and the average attitudes towards change $\left(\mathrm{r}_{(94)}=0.229, \mathrm{p}<0.05\right)$, both with the cognitive $\left(\mathrm{r}_{(94)}=0.247, \mathrm{p}<0.05\right)$ and the emotional attitudes $\left(\mathrm{r}_{(94)}=0.237, \mathrm{p}<0.05\right)$.

In summary, findings revealed a significant weak-to-moderate positive correlation between the TPACK components and the emotional and cognitive attitudes towards change: The higher the teachers scored on TPACK, the more positive their emotional and cognitive attitudes towards change are.

\section{E. Correlation between Attitudes towards Change and the Perception of School as a Learning Organization}

The correlation between the participants' attitudes towards change and their perception of school as a learning organization was examined, using a Pearson test. (Table 6).

Table 6: Correlation between attitudes towards change and the perception of school as a learning organization

\begin{tabular}{lllll}
\hline & $\begin{array}{l}\text { Attitudes } \\
\text { towards } \\
\text { change - } \\
\text { general }\end{array}$ & $\begin{array}{l}\text { Cognitive } \\
\text { attitudes }\end{array}$ & $\begin{array}{l}\text { Emotional } \\
\text { attitudes }\end{array}$ & $\begin{array}{l}\text { Behavioral } \\
\text { attitudes }\end{array}$ \\
\hline Learning processes & 0.104 & 0.037 & 0.145 & 0.073 \\
\hline $\begin{array}{l}\text { Evaluation and drawing conclu- } \\
\text { sions }\end{array}$ & 0.135 & 0.055 & $0.202^{*}$ & 0.065 \\
\hline $\begin{array}{l}\text { Disseminating information and } \\
\text { knowledge }\end{array}$ & 0.153 & 0.108 & 0.192 & 0.066 \\
\hline $\begin{array}{l}\text { Gathering and preserving infor- } \\
\text { mation and knowledge }\end{array}$ & 0.181 & 0.137 & $0.242^{*}$ & 0.049 \\
\hline
\end{tabular}

* Significant at the level of $p<0.05$

Table 6 shows two significant correlations - a significant positive, weak, correlation between emotional attitudes towards change and the perception of school as an organization that maintains processes of evaluation and drawing conclusions $\left(\mathrm{r}_{(95)}=0.202, \mathrm{p}<0.05\right)$, and a weak, positive significant correlation between emotional attitudes towards change and the perception of school as an organization that maintains processes of gathering and preserving information and knowledge $\left(\mathrm{r}_{(95)}=0.242, \mathrm{p}<0.05\right)$.

The finding that the higher the teachers' perception of school as maintaining processes of evaluation and drawing conclusions and processes of gathering and preserving information and knowl- 
edge the more positive are their emotional attitudes towards change clearly indicates the importance of organizational learning processes in improving teachers' solidarity with school.

\section{Discussion and Conclusions}

This study investigated the inter-relationships between the three major factors that affect leading a change in organizations in general and in the context of innovation technology implementation in schools in particular (Archambult \& Crippen, 2009; Cox \& Graham, 2009): (1) the Technological Knowledge, Pedagogical Knowledge, and Content Knowledge of teachers (TPACK), (2) Teachers' attitudes towards change, and (3) teachers' perception of school as a learning organization.

The fact that the highest TPACK score was found for Pedagogic Content Knowledge (PCK) and the lowest score for Technological Knowledge (TK) indicates the well-reported gap between teachers' feelings of control in the content they teach, as opposed to feelings of helplessness and loss of control when they implement technology in their teaching. Similar findings were reported by Archambault and Crippen (2009), who explored factors that affect the implementation of innovative technologies in schools.

In general, the teachers' attitudes towards change were found to be positive, and the fact that the highest scores in the Attitudes towards Change index were found for the behavioral attitudes clearly indicates the readiness of teachers who participated in the implementation project to actively work for creating change. On the other hand, the great variance that was found with respect to their emotional attitudes towards change indicates an inconsistency among the participants concerning the need for change, which may result from heterogeneity in the participating group that consisted of technology-literate and technology illiterate participants.

The importance that teachers assign to maintaining processes and characteristics of a learning organization in their school is evident from the research findings, in which the participants reported of a strong will to be active in making their school a learning organization that enables cooperative learning, consistent feedback, and control. On the other hand, the teachers reported an unsatisfactory preparation of their schools for the implementation of the innovative smart class technology. It is reported from many recent studies that dialogue, cooperation, knowledgetransfer, and knowledge conservation, which are characteristic elements of school as a learning organization, lead to positive attitudes towards change and are important factors in implementing innovative technologies (Cibulka Nakayama, Price, \& Stewart, 2000; Zhao \&, Ordóñez de Pablos, 2009). This illustrates the crucial importance of teachers' participation in the leadership of a change and in decision-making processes in order to strengthen teachers' positive attitudes towards the change (Fullan, 2000; Harris \& Hofer, 2009; Selwyn, 2010; Vaillant, 2005).

Examining the correlation between the three factors (i.e. TPACK, attitudes towards change, and perception of school as a learning organization) revealed two significant correlations:

1. Positive correlation between TPACK (especially Pedagogical and Content Knowledge PK and CK respectively) and attitudes towards change (especially the cognitive and behavioral attitudes).

2. Positive correlation between teachers' attitudes towards change and their perception of school as a learning organization (especially when it maintains processes of evaluation and drawing conclusions and processes of gathering and preserving information and knowledge).

In other words, participants who scored high in TPACK and in perceiving their school as a learning organization also scored high in their positive attitudes towards change. These findings reinforce the claims that the adoption and implementation of change that involves innovation tech- 
nologies is a personal process (Ogobonna, \& Harris, 2009), unique to every teacher and related to his or her personal beliefs and motivations (Darling Hammond, 2000). On the other hand, it is a process of change in the organizational culture (Koehler \& Mishra, 2009) that requires special organizational preparations in order to reduce resistance (Avidov-Ungar, 2010; Mioduser, Nachmias, Lahav, \& Oren, 2000).

The research findings concerning TPACK, attitudes toward change, and perception of school as a learning organization allow employing three perspectives in the analysis of change which takes place in schools that implement innovation technologies: (1) the systemic perspective, as expressed by the School as a Learning Organization index, (2) the professional-personal perspective, as expressed by the TPACK index, and (3) the procedural perspective, as expressed by the teachers' attitudes towards change. The TPACK index consists of elements from the three perspectives (Archambult \& Crippen, 2009; Cox \& Graham, 2009) and, therefore, can be used as a predictor for the potential of teachers to implement innovative technologies effectively in their teaching.

Findings of this research clearly indicate the pivotal role of the co-existence of a learning organizational culture in school, side by side with a high level of teachers' technological-contentpedagogical knowledge, in generating positive attitudes towards the changes that innovative technologies bring and in improving the implementation's success. Future research is required, in order to investigate the actual effect of the TPACK index on the success of innovative technologies implementation in schools.

\section{References}

Archambault, L. \& Crippen, K. (2009). Examining TPACK among K-12 online distance educators in the United States. Contemporary Issues in Technology and Teacher Education, 9(1), 71-88.

Avidov-Ungar, O. (2010). "Islands of innovation" or "Comprehensive innovation". Assimilating educational technology in teaching, learning, and management: A case study of school networks in Israel. Interdisciplinary Journal of E-Learning and Learning Objects, 6, 259-280. Retrieved from http://www.ijello.org/Volume6/IJELLOv6p259-280Avidov704.pdf

Becker, C., \& Lee, M. (2009). The interactive whiteboard revolution: Teaching with IWBs. Victoria, Australia: ACER Press.

Becker, H. (2001). How are teachers using computers in instruction? Paper presented at the 2001 Annual Meeting of the American Educational Research Association, University of California, Seattle.

Cibulka, J., Coursey, S., Nakayama, M., Price, J., \& Stewart, S. (2000). Schools as Learning Organizations: A Review of the Literature. The Creation of High-Performance Schools through Organizational and Individual Learning. (Part One of Three). For full text see http://www.northyorks.gov.uk/CHttpHandler.ashx?id=13127\&p=0 J

Coffman, T. (2009). Getting to the heart of technology integration: Virginia's instructional technology resource teacher program. Learning and Learning with Technology, 36(7), 20-23.

Collinson, V. (2010). To learn or not to learn: A potential organizational learning gap among school systems? Leadership and Policy in Schools, 9(2), 190 - 219.

Coppieters, P. (2005). Turning schools into learning organizations. European Journal of Teacher Education, 28(2), 129-139.

Cox, S., \& Graham, C. R. (2009). Diagramming TPACK in practice: Using an elaborated model of the TPACK framework to analyze and depict teacher knowledge. Tech Trends, 53(5), 60-69.

Cuban, L. (1988). A fundamental puzzle of school reform. Phi Delta Kappan, 69(5), 340-344.

Cunningham, C. A. (2009). Transforming schooling through technology: Twenty-first-century approaches to participatory learning. Education and Culture, 25(2), 46-61. 
Darling-Hammond, L. (2000). Policy and change: Getting beyond bureaucracy. In A. Hargreaves, A. Liberman, M. Fullen, \& D. Hopkins (Eds.), International handbook of educational change. Kluwer Academic Publishers.

Day, C., \& Gu, Q. (2007). Variations in the conditions for teachers' professional learning and development: Sustaining commitment and effectiveness over a career. Oxford Review of Education, 33(4), 423-443.

Day, C., \& Smethem, L. (2009).The effects of reform: Have teachers really lost their sense of professionalism? Journal of Educational Change, 10(2-3), 141-157.

De Freitas, S., \& Oliver, M. (2005). Does e-learning policy drive change in higher education? A case study relating models of organizational change to e-leaning implementation. Journal of Higher Education Policy and Management, 27(1), 81-95.

Del Val, M. P., \& Fuentes, C. M. (2003). Resistance to change: A literature review and empirical study. Management Decision, 41(12), 148-155.

Doering, A., Veletsianos, G., Scharber, C., \& Miller, C. (2009). Using the technological, pedagogical, and content knowledge framework to design online learning environments and professional development. Journal of Educational Computing Research, 41(3), 319-346.

Eshet, Y. (2004). Digital literacy: A conceptual framework for survival skills in the digital era. Journal of Educational Multimedia and Hypermedia, 13(1), 93-106.

Eshet, Y. (2007). Teaching online: Survival skills for the effective teacher. Inroads- The SIGCSE Bulletin, 39(2), 16-20.

Fauske, J. R., \& Raybould, R. (2005). Organizational learning theory in schools. Journal of Educational Administration, 43(1), 22-40.

Fullan, M. (2000). The meaning of educational change: A quarter of a century of learning. In A. Hargreaves, A. Liberman, M. Fullan, \& D. Hopkins (Eds), International handbook of educational change. Kluwer Academic Publishers.

Fullan, M., \& Hargreaves, A. (1996). What's worth fighting for in your school? New York: Teachers College Press.

Fullan, M., \& Smith, G. (1999). Technology and the problem of change. Available at http://www.michaelfullan.ca/Articles_98-99/12_99.pdf

Giles, C., \& Hargreaves, A. (2006). The sustainability of innovative schools as learning organizations and professional learning communities during standardized reform. Educational Administration Quarterly, $42(1), 124-156$.

Halverson, R., \& Smith, A. (2009). How new technologies have (and have not) changed teaching and learning in schools. Journal of Computing in Teacher Education, 26(2), 49-55.

Harris, J., \& Hofer, M. (2009). Instructional planning activity types as vehicles for curriculum-based TPACK development. In C. D. Maddux (Ed.), Research highlights in technology and teacher education 2009. Chesapeake, VA: AACE.

Harris, J., Mishra, P., \& Koehler, M. (2009). Teacher's technological pedagogical content knowledge: Curriculum-based technology integration reframed. Journal of Research on Technology in Education, 41(4), 393-416.

Hattie, J. (2009). Visible learning: A synthesis of over 800 meta-analyses relating to achievement. London and New York: Routledge.

Kent, T. W., \& MacNergney, R. F. (1999). Will technology really change education? California: Corwin Press.

Koehler, M. J., \& Mishra, P. (2008). Introducing technological pedagogical knowledge. In AACTE (Eds.), The handbook of technological pedagogical content knowledge for educators. Routledge/Taylor \& Francis Group for the American Association of Colleges of Teacher Education. 
Koehler, M. J., \& Mishra, P. (2009). What is technological pedagogical content knowledge? Contemporary Issues in Technology and Teacher Education, 9(1), 60-70.

Kontoghiorghes, C., Awbre, S., \& Feurig, P. L. (2005). Examining the relationship between learning organization characteristics and change adaptation, innovation, and organizational performance. Human Resource Development Quarterly Journal, 16(2), 185-212.

Korland, H. (2000). Elementary school as a learning organization. M.A., dissertation, Faculty of Education, Haifa University. [in Hebrew].

Levin, B., \& Fullan, M. (2008). Learning about system renewal. Educational Management Administration \& Leadership, 36(2), 289-303.

Lieberman, A. (1995). Practices that support development transforming conceptions of professional learning. Phi Delta Kappan, 77(7), 591-596.

Mioduser, D., Nachmias, R., Forkosh, B. A., \& Tubin, D. (2004). Sustainability, scalability and transferability of ICT-based pedagogical innovations in Israeli schools. Education, Communication \& Information, 4(1), 71-82.

Mioduser, D., Nachmias, R., Lahav, O., \& Oren, A. (2000). Web-based learning environments: Current pedagogical and technological state. Journal of Research on Computing in Education, 33, 55-77.

Mishra, P., \& Koehler, M. J. (2006). Technological pedagogical content knowledge: A new framework for teacher knowledge. Teachers College Record, 108(6), 1017-1054.

Negroponte, N. (1995). Being digital. New York: Alfred A. Knopf.

Ogobonna, E. \& Harris L. C. (2003). Innovation organizational structure and performance. Journal of Organizational Change Management, 16(5), 512-533.

Polly, D., \& Mims, C. (2009). Designing professional development to support teachers' TPACK and integration of Web 2.0 technologies. In T. T. Kidd \& I. Chen (Eds.), Wired for learning: Web 2.0 guide for educators. Charlotte, NC: Information Age Publishing.

Sandy, L. D. (2010). Social capital, empowerment and educational change: A scenario of permeation of one-to-one technology in school. Journal of Computer Assisted Learning, 26(4), 284-295.

Selwyn, N. (2010). Looking beyond learning: Notes towards the critical study of educational technology. Journal of Computer Assisted Learning, 26(1), 65-73.

Senge, P., Cambron-McCabe, N., Lucas, T., Smith, B., Dutton, J., \& Kleiner, A. (2000). Schools that learn. A fifth discipline fieldbook for educators, parents, and everyone who cares about education. New York: Doubleday/Currency

Shulman, L. S. (1987). Knowledge and teaching: Foundations of the new reform. Harvard Educational Review, 57(1), 1-22.

Tas, A. (2005). Organizational learning in primary schools. Journal of Educational Reform, 14(3), 334350.

Tatnall, A., \& Davey, B. (2003). ICT and training: A proposal for an ecological model of innovation. Educational Technology and Society, 6(1), 14-17.

Vaillant, D. (2005). Educational reform and the role of teachers. Prelac Journal, 1, 38-51.

Wallace, R. M. (2004). A framework for understanding teaching with the internet. American Educational Research Journal, 41(2), 447-488.

Way, J., Lilley, E., Ruster, C., Johnco, S., Mauric, L., \& Ochs, L. (2009). Symposium: Interactive whiteboards and pedagogy in primary classrooms. Paper presented at the Annual Conference of Australian Association for Research in Education. Canberra, Australia. Retrieved December 1, 2010, from http://www.aare.edu.au/09pap/way091149.pdf 
Weldy, T. G., \& Gillis, W. E. (2010). The learning organization: variations at different organizational levels. The Learning Organization, 17(5), 455 - 470

Yu-Lin, W., \& Ellinger, A. D. (2008). Organizational learning and innovation performance: A review of the literature and the development of a conceptual framework and research hypotheses. Paper presented at the Academy of Human Resource Development International Research Conference in the Americas, Panama City, FL.

Zhao, J., \& Ordóñez de Pablos, P. (2009). School innovative management model and strategies: The perspective of organizational learning. Information Systems Management, 26(3) 241-251.

Zimmerman, J. (2006). Why some teachers resist change and what principals can do about it. NASSP Bulletin, 90(3), 238-249.

\section{Biographies}

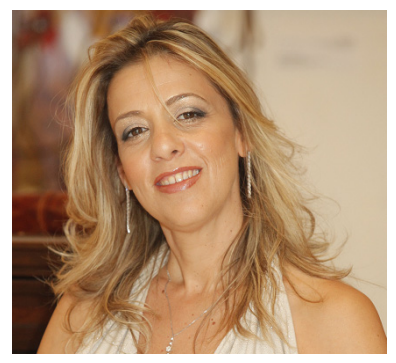

Dr. Orit Avidov-Ungar is a member of the faculty of the Open University in Israel and a senior lecturer at the School of Education Systems Management at Achva College. She is the academic advisor to the Ministry of Education management in the implementation of innovative technology systems and the professional development of teachers.

Her areas of expertise are education administration, changes in education systems, and professional development of teachers. Her research studies deal with the implementation of innovative technologies in education systems, the empowerment and professional development of teachers, and leading organizational change in education systems.

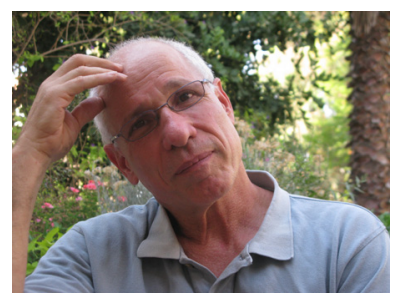

Yoram Eshet is a Full Professor at the Open University of Israel, Department of Education \& psychology. He is the Coordinator of the M.A. program in educational technology and the Founder and Head of the Research Center for Innovation in Learning Technologies.

Yoram has a diverse academic and professional background: He holds a B.A in Archeology, M.Sc. in Geology and PhD in Earth \& Environmental Sciences. For a decade, he was the Head of the Instructional

Design Program in the Tel Hai Academic College and a senior researcher in the Geological Survey of Israel.

Yoram has more than 15 years experience in the educational technology industry - developing technology-based instructional solutions for educational systems in Israel and the USA. In this capacity, he was involved in the design of hundreds of simulations, microworlds, data-bases, tutorials and large-scale curriculum integration projects.

His major research and publications focus mainly on cognitive aspects of working with digital technologies, technology integration in educational systems, digital games and design principles of computer-based learning environments. In geology, his research focuses on chronostratigraphy, mass-extinctions and pleoenvironmental interpretations.

Yoram serves on the editorial board of various international journals, and on the program committees of international conferences.

For a full CV, see: http://www.openu.ac.i1/Personal_sites/yoram-eshet.html 